\title{
HUBUNGAN ANTARA PENGETAHUAN IBU TENTANG GIZI DENGAN STATUS GIZI ANAK UMUR 1- 3 TAHUN DI DESA MOPUSI KECAMATAN LOLAYAN KABUPATEN BOLAANG MONGONDOW INDUK SULAWESI UTARA
}

\author{
${ }^{1}$ Murty Ekawaty M \\ ${ }^{2}$ Shirley E. S. Kawengian \\ ${ }^{2}$ Nova H. Kapantow
}

\author{
${ }^{1}$ Kandidat Skripsi Fakultas Kedokteran Universitas Sam Ratulangi Manado \\ ${ }^{2}$ Bagian Ilmu Gizi Fakultas Kedokteran Universitas Sam Ratulangi Manado \\ Email: murtyekawaty36@gmail.com
}

\begin{abstract}
This study aimed to determine the relationship between mothers' knowledge about nutrition and nutritional status of children aged 1-3 years in the Mopusi village, Lolayan Bolang Mongondow Induk. This was an analytical study with a cross sectional design. There were 90 samples that met the inclusion and exclusion criteria. Data were collected by using anthropometric measurements and questionnaires and then were analyzed by using Spearman's rho test. The results showed that there was $5.6 \%$ samples with nutritional status (BMI/A) very thin, $6.7 \%$ underweight, normal $68.9 \%$, obese $18.9 \%$. The nutritional status (H/A) of the samples was $38.9 \%$ very short, short $12.2 \%$, 45.6\% normal, and tall 3.3\%. There was no relationship of nutritional status of children (BMI/A) with mothers' knowledge about nutrition with $\mathrm{p}=0.480(\mathrm{p}<\alpha=0.05)$ as well as there was no relationship of nutritional status of children (H/A) with knowledge of maternal nutrition in children aged 1-3 years with $p=0.113$ $(\mathrm{p}<\alpha=0.05)$. Conclusion: There was no relationship between nutritional status (BMI/A) as well as (H/A) of children aged 1-3 years with mothers' knowledge about nutrition in Mopusi village, Lolayan Bolaang Mongondow Induk.
\end{abstract}

Keywords: Nutritional Status, Mother's Nutritional Knowledge

\begin{abstract}
Abstrak: Penelitian ini bertujuan untuk mengetahui hubungan antara pengetahuan ibu tentang gizi dengan status gizi anak umur 1-3 tahun di Desa Mopusi Kecamatan Lolayan Kabupaten Bolaang Mongondow Induk. Rancangan penelitian ini bersifat analitik dengan menggunakan pendekatan potong lintang. Sampel merupakan bagian dari populasi yang memenuhi kriteria inklusi dan eksklusi berjumlah 90 orang. Data dikumpulkan melalui pengukuran antropometri dan kuesiener pengetahuan dan dianalisis dengan menggunakan uji Spearman's rho. Hasil penelitian memperlihatkan status gizi (IMT/U) yang sangat kurus 5,6\%, kurus 6,7\%, normal $68,9 \%$, dan obes $18,9 \%$. Status gizi (TB/U) yang sangat pendek $38,9 \%$, pendek $12,2 \%$, normal 45,6\%, dan tinggi 3,3\%. Pengetahuan ibu tentang gizi dengan kategori baik sebanyak 12,2\%, cukup 42,2 \%, dan kurang 45,5\%. Analisis statistik menunjukkan tidak terdapat hubungan status gizi (IMT/U) dan pengetahuan gizi ibu dengan anak umur 1-3 tahun, nilai $p=0,480$ $(p<\alpha=0,05)$, dan tidak terdapat hubungan status gizi $(T B / U)$ dan pengetahuan gizi ibu pada anak umur 1-3 tahun, nilai $p=0,113(p<\alpha=0,05)$. Simpulan: Tidak terdapat hubungan antara status gizi (IMT/U) dan (TB/U) dengan pengetahuan gizi ibu dengan anak umur 1-3 tahun di Desa Mopusi Kecamatan Lolayan Kabupaten Bolaang Mongondow Induk.
\end{abstract}

Kata kunci: status gizi, pengetahuan gizi ibu 
Status gizi khususnya status gizi anak merupakan salah satu indikator kualitas sumber daya manusia yang menentukan tingkat kesejahteraan masyarakat. Status gizi anak batita secara langsung maupun tidak langsung dapat dipengaruhi oleh lingkungan, di mana batita tersebut tumbuh dan berkembang. Faktor-faktor yang mempengaruhi di antaranya: pengetahuan, sikap, dan perilaku ibu. Pengetahuan melambangkan sejauh mana dasar-dasar yang digunakan seorang ibu untuk merawat anak batita sejak dalam kandungan, pelayanan kesehatan, dan persediaan makanan di rumah. ${ }^{1,2}$

Milenium development goals (MDGs) menurunkan hingga setengah dari proporsi anak yang menderita malnutrisi pada tahun tahun 1990 yaitu sebesar 35,5\% menjadi $18 \%$ pada tahun 2015, sedangkan proporsi malnutrisi pada anak tahun 2008 masih tinggi yaitu sebesar 28,7\%, sehingga Indonesia masih perlu bekerja keras untuk mencapai indikator MDGs tersebut. ${ }^{3}$

World Health Organization (WHO) memperkirakan bahwa 54\% penyebab kematian bayi dan balita di dasari oleh keadaan gizi yang buruk. Menurut bank dunia tahun 2002 sekitar 47\% anak-anak India kurang gizi. Malnutrisi pada anakanak sebagian besar disebabkan oleh tingginya infeksi dan kesalahan pemberian makanan pada bayi dan anak-anak sejak lahir hingga tiga tahun. Sekitar 30\% anakanak India dilahirkan dengan berat badan kurang dan umumnya tidak berubah saat besar. $^{4}$

Riskesdas 2007, 2010, 2013 menunjukkan bahwa Indonesia masih memiliki masalah kekurangan gizi. Kecenderungan prevalensi kurus (wasting) anak dari 13,6\% menjadi 13,3\% dan menurun 12,1\%. Sedangkan kecenderungan prevalensi anak balita pendek (stunting) sebesar 36,8\%, 35,6\%, 37,2\%. Prevalensi gizi kurang (underweight) berturut-turut $18,4 \%, 17,9 \%$ dan $19,6 \%{ }^{5}$

Sulawesi Utara pada tahun 2006 dari 33,325 jumlah anak yang diukur ternyata terdapat 0,61\% dengan status gizi buruk, 8,35\% dengan status gizi kurang, 88,38\% status gizi baik dan 2,66\% anak balita dengan status gizi lebih. Data ini juga menunjukkan di kawasan kota Manado dari 2.267 anak balita yang diukur terdapat $1,28 \%$ mengalami gizi buruk, $13,50 \%$ gizi kurang, 81,83\% gizi baik dan 3,40\% yang gizi lebih. ${ }^{6}$ Bolaang Mongondow tahun 2012 jumlah persentase gizi buruk yaitu 0,01\% dari jumlah balita 13.464 yang tidak ditimbang dan 19.263 yang di timbang.

Masyarakat Desa Mopusi Kecamatan Lolayan Kabupaten Bolaang Mongondow Induk khususnya ibu yang memiliki anak usia $1-3$ tahun latar belakang pendidikan kebanyakan dari mereka berpendidikan SD sehingga tingkat pengetahuan terhadap gizi kurang. Selain itu, masih kurangnya tenaga kesehatan dan fasilitas puskesmas/pustu yang tidak memadai sehingga penyuluhan mengenai masalah gizi jarang dilakukan dan hal ini menjadi salah satu faktor penentu pengetahuan seorang ibu terhadap gizi dan masih terdapat beberapa masalah gizi.

\section{METODE PENELITIAN}

Penelitian ini adalah penelitian analitik dengan desain penelitian potong lintang dan dilaksanakan di Desa Mopusi Kecamatan Lolayan Kabupaten Bolaang Mongondow Induk bulan September sampai Desember 2014. Sampel penelitian ini merupakan bagian dari populasi yang memenuhi kriteria inklusi dan eksklusi berjumlah 90 batita diambil melalui metode purposive sampling.

Data dikumpulkan melalui pengukuran antropometri dan kuesioner pengetahuan, kemudian data dianalisis dengan menggunakan uji Spearman's rho.

\section{HASIL PENELITIAN}

\section{Karakteristik sampel dan responden}

Berdasarkan jenis kelamin, sampel laki-laki sebanyak 42,2\% dan perempuan sebanyak 57,8 \%. Berdasarkan umur, batita yang memiliki umur 12-19 bulan sebanyak $46,7 \%$ serta merupakan distribusi terbanyak. Berdasarkan anak ke berapa, batita yang merupakan anak 1 sebanyak $57,8 \%$ serta merupakan distribusi 
terbanyak. Berdasarkan jumlah keluarga yang tinggal di rumah bersama terdapat 3-4 orang memiliki $63,3 \%$ serta merupakan distribusi terbanyak.

Berdasarkan umur ibu, responden yang memiliki umur 15 tahun - 25 tahun sebanyak $71 \%$ serta merupakan distribusi terbanyak. Berdasarkan pekerjaan ibu, responden yang memiliki pekerjaan IRT sebanyak 86,7\% serta merupakan distribusi terbanyak. Berdasarkan latar belakang pendidikan, responden yang memiliki pendidikan lulusan SD sebanyak 41,1\% serta merupakan distribusi terbanyak.

Berdasarkan pekerjaan ayah batita, yang memiliki pekerjaan Wiraswasta yang terdiri dari Petani, Tambang, Supir sebanyak 95,6\% serta merupakan distribusi terbanyak. Berdasarkan latar belakang pendidikan ayah batita, yang mamiliki pendidikan lulusan SMP sebanyak 43,3\% serta merupakan distribusi terbanyak.

Berdasarkan pendapatan orang tua perbulan batita, yang memiliki penghasilan 1-3 juta sebanyak 45,6\% serta merupakan distribusi terbanyak.

\section{Status Gizi}

Berdasarkan hasil penelitian dapat digambarkan pada Tabel 1 status gizi indeks massa tubuh berdasarkan umur (IMT/U) dapat di kategorikan sangat kurus sebanyak 5,6\% serta merupakan distribusi paling rendah, yang di kategorikan kurus sebanyak 6,7\%, yang di kategorikan normal sebanyak 68,9\% serta merupakan distribusi terbanyak, yang di kategorikan gemuk sebanyak 18,9\%.

Berdasarkan status gizi berat badan menurut umur $(\mathrm{BB} / \mathrm{U})$ dapat di kategorikan gizi buruk sebanyak 13,3\%, yang dikategorikan gizi kurang sebanyak 12,2\%, yang dikategorikan gizi baik sebanyak 73,3\% serta merupakan distribusi terbanyak, yang dikategorikan gizi lebih sebanyak $1,1 \%$ serta merupakan distribusi paling rendah (Tabel 1).

Berdasarkan status gizi tinggi badan menurut umur (TB/U) dapat di kategorikan sangat pendek sebanyak 38,9\%, yang dikategorikan pendek sebanyak 12,2\%, yang dikategorikan normal sebanyak 45,6\% serta merupakan distribusi terbanyak, dan yang dikategorikan tinggi sebanyak 3,3\% serta merupakan distribusi paling rendah (Tabel 1).

Berdasarkan status gizi berat badan menurut tinggi badan (BB/TB) dikategorikan sangat kurus sebanyak 1,1\% serta merupakan distribusi paling rendah, yang dikategorikan kurus sebanyak 11,1\%, yang dikategorikan normal sebanyak 78,9\% serta merupakan distribusi terbanyak, yang dikategorikan gemuk sebanyak 8,9\% (Tabel 1).

Tabel 1. Distribusi Status Gizi Anak Batita Menurut IMT/U, BB/U, TB/U, BB/TB

\begin{tabular}{lccc}
\hline \multirow{2}{*}{ Kategori Status Gizi } & \multicolumn{2}{c}{ Jumlah } \\
\cline { 3 - 4 } IMT/U & sangat kurus & 5 & $\%$ \\
& kurus & 6 & 5,6 \\
& normal & 62 & 68,9 \\
& gemuk & 17 & 18,9 \\
BB/U & gizi buruk & 12 & 13,3 \\
& gizi kurang & 11 & 12,2 \\
& gizi baik & 66 & 73,3 \\
& gizi lebih & 1 & 1,1 \\
TB/U & sangat pendek & 35 & 38,9 \\
& pendek & 11 & 12,2 \\
& normal & 41 & 45,6 \\
& tinggi & 3 & 3,3 \\
BB/TB & sangat kurus & 1 & 1,1 \\
& kurus & 10 & 11,1 \\
& normal & 71 & 78,9 \\
& gemuk & 8 & 8,9 \\
\hline
\end{tabular}

Dari hasil penelitian jenis kelamin berdasarkan status gizi (IMT/U), laki -laki dan perempuan yang memiliki status gizi normal masing- masing sebanyak 68,4\% dan $69,2 \%$. Umur batita 12-19 bulan yang memiliki status gzi normal sebanyak 70,3\%. Jumlah keluarga 3-4 orang berstatus gizi normal sebanyak 71,9\%. Umur ibu 15 - 25 tahun memiliki status gizi normal sebanyak 71,9\%. Pekerjaan sebagai Ibu Rumah Tangga yang memiliki batita dengan status gizi normal sebanyak 66,7\%. Pendapatan orang tua perbulan yang memiliki status gizi normal sebanyak 25 (61\%). 
Dari hasil penelitian jenis kelamin berdasarkan status gizi (TB/U), laki -laki dan perempuan yang memiliki status gizi normal masing- masing sebanyak 42,1\% dan $48,1 \%$. Umur batita $12-19$ bulan yang memiliki status gizi normal sebanyak 45,2\%. Jumlah keluarga 3-4 orang berstatus gizi normal sebanyak 49,1\%. Umur ibu 1525 tahun memiliki status gizi normal sebanyak 48,4\%. Pekerjaan sebagai Ibu Rumah Tangga yang memiliki batita dengan status gizi normal sebanyak 44,9\%. Pendapatan orang tua perbulan yang memiliki status gizi normal sebanyak $42,9 \%$.

\section{Pengetahuan Gizi}

Pengetahuan gizi ibu anak umur 1-3 tahun dinilai berdasarkan pertanyaanpertanyaan pada kuesioner yang dijawab oleh para responden. Jumlah responden yang berpengetahuan kurang lebih banyak dari yang berpengetahuan baik. Sebanyak $12,2 \%$ berpengetahuan baik mengenai gizi, $42,2 \%$ berpengetahuan cukup, dan 45,6\% berpengetahuan kurang (Tabel 2).

Tabel 2. Distribusi Pengetahuan Gizi Ibu

\begin{tabular}{ccc}
\hline Pengetahuan Gizi & \multicolumn{2}{c}{ Jumlah } \\
\cline { 2 - 3 } Ibu & $\mathrm{n}$ & $\%$ \\
\hline Baik & 11 & 12,2 \\
Sedang & 38 & 42,2 \\
Kurang & 41 & 45,6 \\
\hline
\end{tabular}

Berdasarkan hasil penelitian diketahui bahwa, umur ibu 15 - 25 tahun yang memiliki pengetahuan kurang menjadi distribusi tertinggi yaitu sebanyak 46,9\%. Pekerjaan responden sebagai ibu rumah tangga (IRT) memiliki pengetahuan yang kurang dengan distribusi tertinggi sebanyak $50 \%$. Pendidikan responden SD merupakan distribusi tertinggi untuk responden berpengetahuan kurang sebanyak 89,2\%.

\section{Hubungan Pengetahuan Gizi Ibu dengan Status Gizi}

Hubungan antara status gizi dengan pengetahuan gizi ibu di Desa Mopusi Kecamatan Lolayan Kabupaten Bolaang
Mongondow Induk dilakukan pengujian statistik dengan menggunakan uji korelasi Spearman (Tabel 3).

Berdasarkan hasil uji statistik, hubungan status gizi (IMT/U) dengan pengetahuan gizi ibu didapatkan nilai koefisien korelasi (r) sebesar -0,075 dan nilai $\mathrm{p}=0,480<\alpha=0,05$. Hal ini menunjukkan bahwa tidak terdapat hubungan status gizi (IMT/U) dengan pengetahuan gizi ibu pada anak umur 1- 3 tahun di Desa Mopusi Kecamatan Lolayan Kabupaten Bolaang Mongondow Induk.

Berdasarkan hasil uji statistik, hubungan status gizi (TB/U) dengan pengetahuan gizi ibu didapatkan nilai koefisien korelasi (r) sebesar 0,168 dan nilai $\mathrm{p}=0,113<\alpha=0,05$. Hal ini menunjukkan bahwa tidak terdapat hubungan status gizi (TB/U) dengan pengetahuan gizi ibu pada anak umur 1- 3 tahun di Desa Mopusi Kecamatan Lolayan Kabupaten Bolaang Mongondow Induk.

Tabel 3. Hubungan status gizi dengan pengetahuan gizi ibu

\begin{tabular}{|c|c|c|}
\hline Variabel Penelitian & $r$ & $p$ \\
\hline $\begin{array}{l}\text { Status Gizi (IMT/U) } \\
\text { Pengetahuan Gizi Ibu }\end{array}$ & -0.075 & 0.480 \\
\hline $\begin{array}{l}\text { Status Gizi (BB/U) } \\
\text { Pengetahuan Gizi Ibu }\end{array}$ & 0.038 & 0.721 \\
\hline $\begin{array}{l}\text { Status Gizi (TB/U) } \\
\text { Pengetahuan Gizi Ibu }\end{array}$ & 0.168 & 0.113 \\
\hline $\begin{array}{l}\text { Status Gizi (BB/TB) } \\
\text { Pengetahuan Gizi Ibu }\end{array}$ & 0.023 & 0.831 \\
\hline
\end{tabular}

\section{BAHASAN}

Jenis kelamin merupakan faktor internal yang menentukan kebutuhan gizi sehingga ada keterkaitan antara jenis kelamin dengan keadaan gizi batita. ${ }^{7}$

Masalah gizi pada anak usia ini sesuai dengan penelitian yang dilakukan oleh Turnip (2008) yang menyatakan bahwa anak usia 12-24 bulan berada pada masa perkembangan kritis terutama perkembangan otak, sehingga membutuhkan zat gizi yang baik, namun karena berbagai masalah seperti kurangnya perhatian orang 
tua, penyakit infeksi serta asupan gizi yang kurang mengakibatkan timbulnya berbagai masalah gizi pada anak. Jumlah keluarga yang besar akan mempengaruhi proporsi makanan dalam keluarga dan pengetahuan ibu. $^{7}$

Usia adalah umur individu yang terhitung mulai dari saat dilahirkan sampai saat berulang tahun. Usia akan memengaruhi terhadap daya tangkap dan pola pikir seseorang terhadap informasi yang diberikan. Usia juga menjadi faktor penentu dalam tingkat pengetahuan, pengalaman, keyakinan dan motivasi sehingga umur mempengaruhi perilaku seseorang terhadap objek tertentu. ${ }^{12}$

Pendidikan formal ibu mempengaruhi tingkat pengetahuan ibu dimana semakin tinggi pula tingkat pengetahuan ibu untuk menyerap pengetahuan praktis dalam lingkungan formal maupun non formal terutama melalui media massa, sehingga ibu dalam mengolah, menyajikan dan membagi sesuai yang dibutuhkan. IRT berpengetahuan kurang karena hal ini memungkinkan kurangnya perhatian responden terhadap penyakit pada bayinya karena survei di lapangan menunjukkan baha banyaknya ibu-ibu yang bercerita dengan tetangganya dan tidak mempunyai waktu untuk anaknya. ${ }^{13}$

Pengetahuan akan memudahkan seseorang untuk menyerap informasi dan mengimplentasikannya dalam perilaku dan gaya hidup sehari-hari. Faktor-faktor yang mempengaruhi pengetahuan yaitu umur, pendidikan, dan pengalaman. Semakin cukup umur, tingkat pematangan dan kekuatan seseorang akan lebih matang dalam berpikir, belajar, dan bekerja sehingga pengetahuanpun akan bertambah. ${ }^{9}$

Pengetahuan gizi kerap dipengaruhi oleh tingkat pendidikan yang berdampak pada peran dalam penyusunan makan keluarga, serta pengasuhan dan peraatan anak. $^{8}$

Hasil tersebut menunjukkan bahwa masih terdapat anak usia 1-3 tahun dengan masalah gizi. Hasil penelitian tersebut sesuai dengan penelitian yang dilakukan oleh Devi pada tahun 2010 yang menyatakan bahwa dari 1200 terdapat 582 (49\%) dengan masalah gizi kurang. Masalah gizi pada anak ini disebabkan oleh berbagai penyebab, salah satu penyebab masalah gizi pada anak ialah akibat konsumsi makanan yang tidak baik, sehingga energi yang masuk dan keluar tidak seimbang. Tubuh memerlukan pemilihan makanan yang baik agar kebutuhan zat gizi terpenuhi dan fungsi tubuh berjalan dengan baik. ${ }^{10}$

Penelitian ini sejalan dengan penelitian sebelumnya oleh Asriani, Andi Fajriansi, Sumira tentang hubungan antara pola asuh, pengetahuan, dan sikap orang tua terhadap status gizi balita di Kelurahan Lampa Kecamatan Duampanua Kabupaten Pinrang yang dilakukan pada 74 responden menyatakan bahwa pengetahuan gizi ibu dengan status gizi balita mempunyai nilai $\mathrm{p}$ 0,416 sehingga tidak ada hubungan yang bermakna antara pengetahuan gizi ibu dengan status gizi balita. ${ }^{9}$ Hal ini juga sejalan dengan penelitian yang dilakukan oleh Mahardika mengenai hubungan anatara pendapatan keluarga dan pengetahuan gizi ibu dengan status gizi balita di Desa Selodoko Kecamatan Ampel Kabupaten Boyolali yang menyatakan baha pengetahuan gizi ibu dengan status gizi balita mempunyai nilai $\mathrm{p}=0,110$ sehingga tidak ada hubungan antara pengetahuan ibu dengan status gizi balita. ${ }^{11}$

Hasil penelitian ini tidak sesuai dengan penelitian yang dilakukan Susanti, Indriati, dan Utomo tentang hubungan pengetahuan ibu tentang gizi dengan status gizi anak umur 1- 3 tahun pada 98 responden di wilayah kerja Puskesmas Rojosari yang menyatakan bahwa terdapat hubungan bermakna antara pengetahuan ibu tentang gizi dengan status gizi anak umur 1-3 tahun (nilai p 0,004). ${ }^{12}$

Keadaan ini bisa juga disebabkan karena pengetahuan merupakan penyebab tidak langsung gangguan gizi pada batita, masih ada faktor langsung seperti pola konsumsi, penyakit infeksi, faktor sosial dan ekonomi. Kecukupan pangan di tingkat keluarga belum tentu menjamin perbaikan status gizi setiap individu anggotanya 
apabila tidak disertai dengan pengetahuan dan kemampuan mengolah makanan dan cara pemberian makanan pada anak meskipun bahan makanan sudah tersedia. ${ }^{9}$

\section{SIMPULAN}

Pengetahuan ibu mengetahui gizi yang terbanyak dengan kategori kurang. Status gizi IMT/U terbanyak yaitu normal. Status gizi TB/U yang terbanyak normal. Tidak terdapat hubungan status gizi (IMT/U) dan status gizi $(\mathrm{TB} / \mathrm{U})$ dengan pengetahuan gizi ibu pada anak umur 1-3 tahun di Desa Mopusi Kecamatan Lolayan Kabupaten Bolaang Mongondow Induk.

\section{SARAN}

Berdasarkan hasil yang didapatkan pada penelitian ini, maka perlu diajukan saran sebagai berikut:

1. Status gizi batita yang baik perlu dipertahankan dan yang mengalami status gizi yang kurang perlu diperhatikan dengan rutin melakukan penimbangan di posyandu.

2. Pengetahuan gizi yang baik perlu dipertahankan dan yang kurang perlu ditingkatkan melalui penyuluhan.

3. Perlu dilakukan penelitian lebih lanjut tentang status gizi dengan pengetahuan gizi ibu yang berhubungan dengan faktor-faktor lain.

\section{DAFTAR PUSTAKA}

1. Sartika AD. Analisis Pemanfaatan Program Yankes Status Gizi Balita. Jurnal Kesmas Nas. 2010. h. 5.

2. Wahyudi J. Segi Status Gizi Balita dari Beberapa Faktor Yang Berpengaruh di Desa Tertinggal Alur Bandung Kalimantan Barat. (online). [cited 2014 Oct 2]. Available from: http://www.kalbe.co.id/files/cdk/files/sigist atusgizi103.pdf/sigistatusgizi103.html

3. Svedberg P. Declining child malnutrition: a reassessment. Int J Epidemiol. 2006;35 (5):1336-46.

4. WHO. 2002. [cited 2014 Oct 2]. Available from: http://www.who.int/childgrowth/software/e $\mathrm{n}$

5. Riset kesehatan dasar (RISKESDAS). 2013. [cited 2014 Oct 3]. Available from: http://www.depkes.go.id/resources/downlo ad/general/Hasil\%20Riskesdas\%202013.pd $\mathrm{f}$

6. Propil Pembangunan Sulawesi Utara. 2006. [cited 2014 Oct 7]. Available from: http://simreg.bappenas.go.id/document/Pro fil/Profil\%20Pembangunan\%20Provinsi\%2 07100SulUt\%202013.pdf

7. Farhan M. Hubungan Pengetahuan Ibu Rumah Tangga Tentang Gizi Seimbang dengan Perilaku Pemenuhan Gizi Pada Balita Usia 3-5 tahun di Desa Banjarsari Kecamatan Ciawi Kabupaten Bogor (Skripsi). Jakarta: UIN Syarif Hidayatullah, 2014.

8. Profil keacamatan se Kabupaten Bolaang Mongondow. 2011. [cited 2015 Jan 29]. Available from: https://humasbolmong.files.wordpress.com/ 2011/11/profil-kecamatan-se-kab-bolmong2011.pdf

9. Asriani, F Andi, Sumira. Hubungan antara pola asuh, pengetahuan dan sikap orang tua terhadap status gizi balita di Kelurahan Lampa Kecamatan Duampanua Kabupaten Pinrang. Makassar: Poltekes Kemenkes Makassar. 2013;1(6).

10. Devi M. Analisis faktor- faktor yang berpengaruh terhadap gizi balita dipedesaan. Tehknologi dan Kejuruan. 2010;33(2):183-92.

11. Mahardika. Hubungan antara pendapatan keluarga dan pengetahuan gizi ibu dengan status gizi balita di Desa Selodoko Kecamatan Ampel Kabupaten Boyolali. Boyolali, 2012.

12. Susanti S, Indriati G, Utomo W. Hubungan Pengetahuan Ibu Tentang Gizi Dengan Status Gizi Anak usia 1-3 tahun. Riau: Universitas Riau. 2013.

13. Simanjuntak N.E. Gambaran pengetahuan Ibu Tentang Pola Pemberian ASI, MP-ASI dan Pola Penyakit pada Bayi 0-12 bulan Di dusun III desa Limau Manis Kecamatan Tanjung Kabupaten Deli Serdang. Medan: FKM Universitas Sumatera Utara, 2007. 